\title{
Long-term ethanol consumption leads to lung tissue oxidative stress and injury
}

\author{
Subir Kumar Das ${ }^{1, *}$ and Sukhes Mukherjee ${ }^{2}$ \\ 'Department of Biochemistry; ESI-PGIMSR; Joka, Kolkata; ${ }^{2}$ Amrita Institute of Medical Sciences; Cochin, Kerala India
}

Key words: ethanol, glutathione, lung, oxidative stress, reactive oxygen species

Abbreviations: ARDS, acute respiratory distress syndrome; ECM, extracellular matrix; GSH, reduced glutathione; GSSG, oxidized glutathione; GPx, glutathione peroxidase; GR, glutathione reductase; GST, glutathione s-transferase; LPO, lipid peroxidation; MMP, matrix metalloproteinase; ROS, ractive oxygen species; SOD, superoxide dismutase; TBA, thiobarbituric acid; TBARS, thiobarbituric acid reactive substances; TCA, trichloroacetic acid

Background: Alcohol abuse is a systemic disorder. The deleterious health effects of alcohol consumption may result in irreversible organ damage. By contrast, there currently is little evidence for the toxicity of chronic alcohol use on lung tissue. Hence, in this study we investigated long-term effects of ethanol in the lung.

Results: Though body weight of rats increased significantly with duration of exposure compared to its initial weight, there was no significant change in relative weight $(\mathrm{g} / 100 \mathrm{~g}$ body weight) of lung due to ethanol exposure. The levels of thiobarbituric acid reactive substances (TBARS), nitrite, protein carbonyl, oxidized glutathione (GSSG), redox ratio (GSSG/ GSH) and GST activity elevated; while reduced glutathione (GSH) level and activities of glutathione reductase (GR), glutathione peroxidase (GPX), catalase, superoxide dismutase (SOD) and $\mathrm{Na}^{+} \mathrm{K}^{+} \mathrm{ATP}$ ase reduced significantly with duration of ethanol exposure in the lung homogenate compared to the control group. Total matrix metalloproteinase activity elevated in the lung homogenate with time of ethanol consumption. Histopathologic examination also demonstrated that severity of lung injury enhanced with duration of ethanol exposure.

Methods: $16-18$ week-old male albino Wistar strain rats weighing 200-220 g were fed with ethanol (1.6 g/kg body weight/day) up to 36 weeks. At the end of the experimental period, blood samples were collected from reteroorbital plexus to determine blood alcohol concentration and the animals were sacrificed. Various oxidative stress-related biochemical parameters, total matrix metalloproteinase activity and histopathologic examinations of the lung tissues were performed.

Conclusions: Results of this study indicate that long-term ethanol administration aggravates systemic and local oxidative stress, which may be associated with lung tissue injury.

\section{Introduction}

The deleterious health effects of alcohol consumption may result in irreversible organ damage. ${ }^{1}$ By contrast; the ravages of alcohol abuse have been viewed as relatively sparing the lung. More than two centuries ago, Benjamin Rush, the first Surgeon General of the United States, noted that pneumonia and tuberculosis were infectious complications more commonly encountered in people who drank alcohol, and a century later, alcohol abuse as the major risk factor for pneumonia was cited. ${ }^{2}$ This risk has largely been attributed to alterations in immune function and/or structural/ functional defects in the upper airway. In fact, until relatively recently it had been generally assumed that chronic alcohol abuse had no effect on the lung itself. ${ }^{3}$ However, one epidemiological finding revealed that alcohol abuse independently increased the risk for developing the acute respiratory distress syndrome
(ARDS), ${ }^{4}$ a devastating form of acute lung injury in which the air spaces become flooded with inflammatory cells and debris, leading to respiratory failure and may cause death. ${ }^{5}$

Ethanol, being soluble both in water and lipids, can diffuse rapidly through the mucous membrane of the esophagous and stomach. After its absorption ethanol appears in both expired air and in urine. It is not stored in the body, as whatever is ingested is oxidized. ${ }^{6,7}$ When consumed in moderate amounts, the major part of the ethanol is metabolized primarily in the liver by alcohol dehydrogenase, ${ }^{8}$ a cytosolic enzyme with multiple isoforms. ${ }^{9}$ Alcohol can also be metabolized in microsomes via the cytochrome P-450 component CYP2E1. ${ }^{10}$ This enzyme complex has a lower affinity for alcohol than the hepatic alcohol dehydrogenase enzyme and therefore may not contribute significantly to overall alcohol metabolism following occasional use. ${ }^{9}$ Alcohol is metabolized in the lung through the cytochrome P-450 system. ${ }^{11}$ 
Table 1. Body weight, relative weight of lung and plasma ethanol profile of ethanol treated rats for different time period

\begin{tabular}{|c|c|c|c|c|c|c|c|}
\hline Parameters & $\begin{array}{l}\text { Control } \\
\text { (0 week) }\end{array}$ & 4 week & 12 week & 24 week & 36 week & F variance & Significance \\
\hline Ethanol consumption/day & Nil & $1.6 \mathrm{~g} / \mathrm{kg}$ & $1.6 \mathrm{~g} / \mathrm{kg}$ & $1.6 \mathrm{~g} / \mathrm{kg}$ & $1.6 \mathrm{~g} / \mathrm{kg}$ & - & - \\
\hline $\begin{array}{l}\text { Relative weight of lung } \\
\text { ( } \mathrm{g} / 100 \mathrm{~g} \text { body weight) }\end{array}$ & $0.65 \pm 0.02$ & $0.62 \pm 0.02$ & $0.64 \pm 0.01$ & $0.65 \pm 0.02$ & $0.62 \pm 0.02$ & 2.334 & 0.083 \\
\hline Plasma alcohol level (mM) & - & $54.83 \pm 3.06$ & $53.33 \pm 2.73$ & $52.0 \pm 2.36$ & $52.67 \pm 1.96$ & 647.142 & $<0.001$ \\
\hline
\end{tabular}

Values are mean \pm SD of 6 rats in each group. $p$ values: ${ }^{a}<0.001$ compared to control group (Group 1); ${ }^{b}<0.001$ compared to 4 week ethanol treated group (Group 2); ${ }^{c}<0.01$ compared to 12 week ethanol treated group (Group 3). No significant change was observed between 24 weeks and 36 weeks of ethanol exposed rats.

Table 2. Effect of ethanol on thiobarbituric acid reactive substances (TBARS), nitrite, protein-carbonyl, reduced glutathione (GSH) and oxidized glutathione (GSSG) levels and on redox ratios (GSSG/GSH) of lung homogenate

\begin{tabular}{|c|c|c|c|c|c|c|}
\hline & TBARS* & Nitrite $^{\#}$ & Protein-Carbonyl ${ }^{f}$ & $\mathbf{G S H}^{\Psi}$ & GSSG $^{\Psi}$ & Redox ratio \\
\hline Control (0 week) & $0.51 \pm 0.02$ & $13.46 \pm 0.76$ & $0.97 \pm 0.13$ & $7.00 \pm 0.09$ & $0.58 \pm 0.01$ & $0.08 \pm 0.001$ \\
\hline 4 week & $0.71 \pm 0.07$ & $20.33 \pm 2.66^{a}$ & $1.6 \pm 0.14^{a}$ & $6.68 \pm 0.12$ & $0.60 \pm 0.02$ & $0.09 \pm 0.003$ \\
\hline 12 week & $0.86 \pm 0.16^{b}$ & $24.48 \pm 2.45^{\mathrm{a}, \mathrm{e}}$ & $1.88 \pm 0.22^{\mathrm{a}}$ & $4.12 \pm 0.21^{\mathrm{a}, \mathrm{d}}$ & $0.62 \pm 0.01^{c}$ & $0.15 \pm 0.005^{a, d}$ \\
\hline 24 week & $0.97 \pm 0.17^{\mathrm{a}, \mathrm{f}}$ & $28.8 \pm 1.57^{\mathrm{a}, \mathrm{d}, \mathrm{h}}$ & $2.21 \pm 0.19^{\mathrm{a}, \mathrm{d}, \mathrm{i}}$ & $3.83 \pm 0.31^{\mathrm{a}, \mathrm{d}}$ & $0.69 \pm 0.02^{\mathrm{a}, \mathrm{d}, \mathrm{g}}$ & $0.18 \pm 0.012^{\mathrm{a}, \mathrm{d}, \mathrm{i}}$ \\
\hline 36 week & $1.0 \pm 0.17^{\mathrm{a}, \mathrm{e}}$ & $31.26 \pm 1.3^{\mathrm{a}, \mathrm{d}, \mathrm{g}}$ & $2.33 \pm 0.17^{\mathrm{a}, \mathrm{d}, \mathrm{h}}$ & $3.66 \pm 0.33^{\mathrm{a}, \mathrm{d}, \mathrm{i}}$ & $0.71 \pm 0.03^{\mathrm{a}, \mathrm{d}, \mathrm{g}}$ & $0.19 \pm 0.019^{\mathrm{a}, \mathrm{d}, \mathrm{i}}$ \\
\hline F variance & 13.822 & 83.949 & 57.092 & 288.715 & 44.024 & 145.532 \\
\hline Significance & $<0.001$ & $<0.001$ & $<0.001$ & $<0.001$ & $<0.001$ & $<0.001$ \\
\hline
\end{tabular}

Values are mean \pm SD of 6 rats in each group. p values: ${ }^{\mathrm{a}}<0.001,{ }^{\mathrm{b}}<0.01,{ }^{\mathrm{c}}<0.05$ compared to control group (Group 1 ) ${ }^{\mathrm{d}}<0.001,{ }^{\mathrm{e}}<0.01,{ }^{\mathrm{f}}<0.05$ compared to 4 week ethanol treated group (Group 2); ${ }^{9}<0.001,{ }^{h}<0.01,{ }^{i}<0.05$ compared to 12 week ethanol treated group (Group 3). No significant change was observed between 24 weeks and 36 weeks of ethanol exposed rats ${ }^{*}, \mu$ mole MDA formed/min/100 mg tissue; ${ }^{\#}$, nmole/g wet tissue; ${ }^{f}$, nmole/mg protein; $\Psi, \mu \mathrm{g} / \mathrm{mg}$ tissue.

In addition, during alcohol ingestion, alcohol freely diffuses from the bronchial circulation directly through the ciliated epithelium where it vaporizes as it moves into the conducting airways. Moreover, vaporized alcohol can deposit back into the airway lining fluid to be released again into the airways during exhalation. This "recycling" of alcohol vapor results in repeated exposure of the airway epithelium to high local concentrations of alcohol. ${ }^{12}$

Therefore, we investigated long-term effects of ethanol in the lung in this study.

\section{Results}

Body weight of ethanol exposed rats increased significantly after 12 weeks compared to the control group ( 0 week) and continued to increase (Table 1). However, there was no significant change in relative weight ( $\mathrm{g} / 100 \mathrm{~g}$ body weight) of lung with duration of ethanol exposure (Table 1). Once exposed to ethanol, plasma alcohol levels remain unchanged in rats (Table 1).

Ethanol exposure significantly increased nitrite and protein carbonyl content after 4 weeks; thiobarbituric acid reactive substances (TBARS) level, oxidized glutathione (GSSG) content and redox ratio (GSSG/GSH) after 12 weeks; while significantly decreased reduced glutathione (GSH) level after 12 weeks in comparison to the control group in the lung homogenate (Table 2).

Compared to control group, ethanol exposure significantly reduced GPx and $\mathrm{Na}^{+} \mathrm{K}^{+} \mathrm{ATPase}$ activities after 4 weeks, while glutathione reductase (GR), catalase and superoxide dismutase
(SOD) activities after 12 weeks in the lung homogenate (Table 3). However, GST activity increased significantly after 12 weeks of ethanol exposure compared to the control (0 weeks) or 4 weeks of ethanol exposed groups (Table 3). Moreover, there were significant differences in glutathione peroxidase (GPx), glutathione s-transferase (GST) and catalase activities between 12 weeks and 24 weeks of ethanol exposure (Table 3). Interestingly, no significant change in these oxidative stress related parameters was observed between 24 weeks and 36 weeks of ethanol exposed lung homogenates of rats (Tables 2 and 3 ).

Total matrix metalloproteinase (MMP) activity increased significantly in ethanol exposed lung tissues. The activity showed a progressive increase, attaining maximum on $24^{\text {th }}$ week after ethanol exposure (Fig. 1A and B). Histopathological analysis showed that the broncholar and normal alveolar structure was preserved in the control specimen (Fig. 2A), wheras degenerative alveolar structures and leukocytic infiltration were observed in the lung tissues of the ethanol exposed groups (Fig. 2B-E). Severity of inflammation increased with duration of ethanol exposure (Fig. 2B-E). In the controls, median scores of leukocyte infiltration were mainly under 0 and 1 , whereas this score and severity of infiltration increased with duration of ethanol exposure (Table 4).

\section{Discussion}

The intragastric ethanol infusion technique allowed maximal ethanol consumption and absolute control over ethanol-induced 
Table 3. Effect of ethanol on glutathione reductase (GR), glutathione peroxidase (GPx), glutathione s-transferase (GST), catalase, superoxide dismutase (SOD) and $\mathrm{Na}^{+} \mathrm{K}^{+}$-ATPase activities in lung homogenate

\begin{tabular}{|c|c|c|c|c|c|c|}
\hline & $\mathbf{G R}^{*}$ & GPx ${ }^{*}$ & GST $^{\#}$ & Catalase $^{f}$ & SOD $^{\Psi}$ & $\mathrm{Na}^{+} \mathbf{K}^{+}-\mathrm{ATPase}^{\omega}$ \\
\hline Control (0 week) & $14.95 \pm 1.26$ & $24.82 \pm 0.71$ & $4.43 \pm 0.08$ & $3.26 \pm 0.08$ & $1.36 \pm 0.08$ & $223 \pm 9.55$ \\
\hline 4 week & $13.38 \pm 1.07$ & $19.57 \pm 1.24^{\mathrm{a}}$ & $4.5 \pm 0.09$ & $3.1 \pm 0.09$ & $1.28 \pm 0.09$ & $171 \pm 10.41^{a}$ \\
\hline 12 week & $11.35 \pm 0.89^{a, e}$ & $15.67 \pm 1.5^{a, d}$ & $6.58 \pm 0.26^{\mathrm{ad}}$ & $2.91 \pm 0.11^{\mathrm{a}, \mathrm{f}}$ & $1.08 \pm 0.11^{\mathrm{a}, \mathrm{f}}$ & $134.3 \pm 7.2^{a, d}$ \\
\hline 24 week & $10.12 \pm 0.77^{a, d}$ & $13.15 \pm 0.79^{a, d, i}$ & $7.13 \pm 0.28^{\mathrm{a}, \mathrm{d}, \mathrm{h}}$ & $2.65 \pm 0.1^{\mathrm{a}, \mathrm{d}, \mathrm{h}}$ & $0.97 \pm 0.1^{\mathrm{a}, \mathrm{d}}$ & $124 \pm 8^{a, d}$ \\
\hline 36 week & $9.07 \pm 1.04^{\mathrm{a}, \mathrm{d}, \mathrm{h}}$ & $11.67 \pm 1.42^{\mathrm{a}, \mathrm{d}, \mathrm{g}}$ & $7.5 \pm 0.37^{\mathrm{a}, \mathrm{d}, \mathrm{g}}$ & $2.58 \pm 0.11^{\mathrm{a}, \mathrm{d}, \mathrm{g}}$ & $0.93 \pm 0.08^{a, d}$ & $118.5 \pm 12.48^{a, d}$ \\
\hline Fvariance & 41.465 & 113.506 & 212.244 & 47.752 & 23.292 & 120.875 \\
\hline Significance & $<0.001$ & $<0.001$ & $<0.001$ & $<0.001$ & $<0.001$ & $<0.001$ \\
\hline
\end{tabular}

Values are mean \pm SD of 6 rats in each group. p values: ${ }^{\mathrm{a}}<0.001,{ }^{\mathrm{b}}<0.01,{ }^{\mathrm{c}}<0.05$ compared to control group (Group 1 ); ${ }^{\mathrm{d}}<0.001,{ }^{\mathrm{e}}<0.01,{ }^{\mathrm{f}}<0.05$ compared to 4 week ethanol treated group (Group 2); ${ }^{9}<0.001,{ }^{h}<0.01,{ }^{i}<0.05$ compared to 12 week ethanol treated group (Group 3). No significant change was observed between 24 weeks and 36 weeks of ethanol exposed rats. ", nmole NADPH breakdown/min/mg protein; ", $\mu$ mole CDNB conjugate formed/ $\mathrm{min} / \mathrm{mg}$ protein; ${ }^{f}, \mu$ mole $\mathrm{H}_{2} \mathrm{O}_{2}$ decomposed/min/mg protein; ${ }^{\Psi}$, One unit of the enzyme was the amount of SOD capable of inhibiting by $50 \%$ the rate of NADH oxidation observed in the control. The specific activity was expressed as units/mg protein; ${ }^{\omega}, \mathrm{nmole} \mathrm{Pi/mg/protein/h}$.

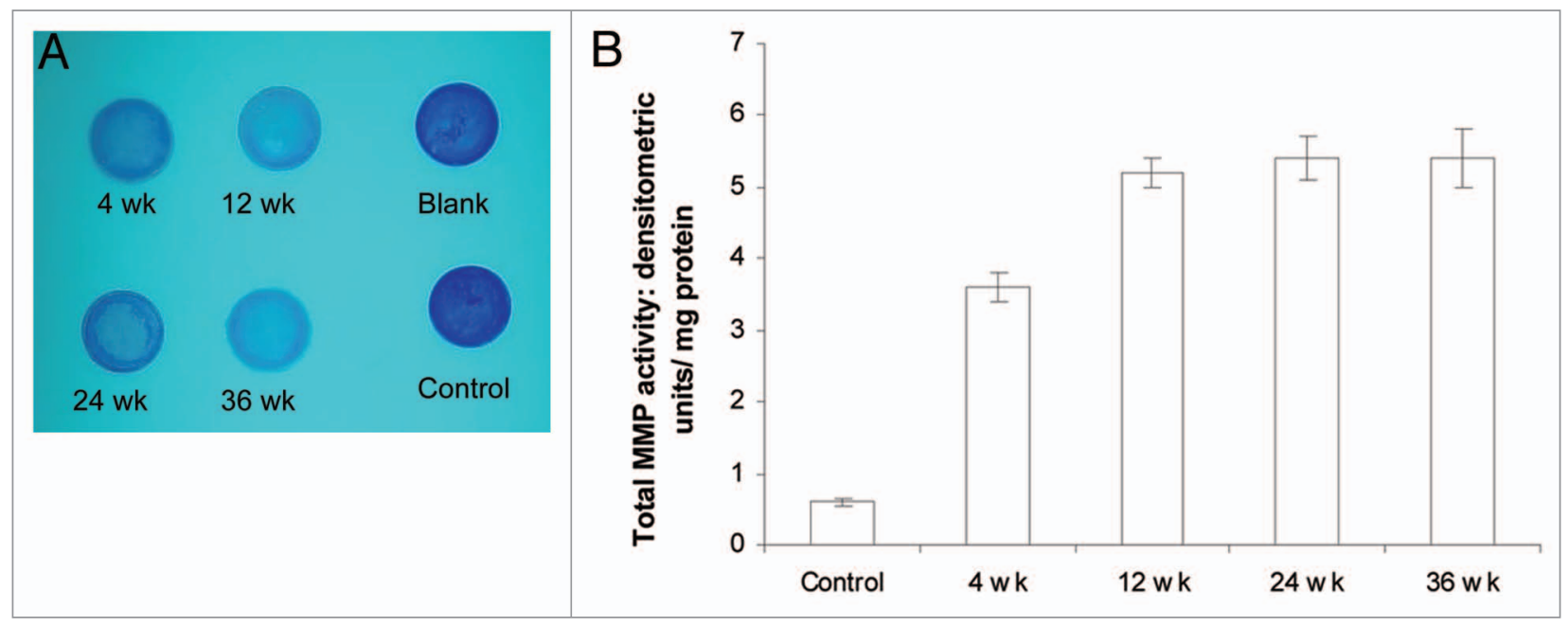

Figure 1. Changes in the total activity of matrix metalloproteinases in ethanol exposed rat lung with time. Rats were fed with ethanol (1.6 $\mathrm{g} / \mathrm{kg}$ body weight/day). (A) Extracts of lung tissue samples $(100 \mu \mathrm{l})$ from control and ethanol exposed rats of different time interval (up to 36 weeks) were copolymerised with acrylamide-bisacryamide containing gelatin in Tris buffer $(\mathrm{pH}$ 8.8). After polymerization, the gels were then incubated in substrate buffer, stained with Coomasie brilliant blue and destained with methanol-acetic acid-water. A blank was prepared without enzyme. (B) Activity measured by densitometric analysis. Values given are average of 3 experiments $\pm S D$.

organ injury. In the present study, a dose of ethanol $1.6 \mathrm{~g} / \mathrm{kg}$ body weight/day was used based on our previous observation, ${ }^{13}$ where we found that this amount of ethanol exposure was tolerable for long period, causing organ damage and is partially reversebile during abstaining. ${ }^{14}$ However, continuous ethanol exposure maintained plasma ethanol level in a steady state in our study (Table 1) is in agreement with other report. ${ }^{15}$ It is also assumed that alcohol metabolism through the cytochrome $\mathrm{p}-450$ system in the lung is significant ${ }^{11}$ and may be sufficient to exert significant oxidative stress in the lung, ${ }^{16,17}$ due to their unique structure and function. ${ }^{18}$

Reactive oxygen species (ROS) are constantly produced in the cells, but under normal physiological conditions the enzymatic and non-enzymatic antioxidant mechanisms of the cell overcome the destructive potential of ROS. There is a delicate balance between the production of ROS and endogenous protection mechanisms. Overproduction of ROS or a decrease in antioxidants results in oxidative stress, and may cause cellular damage by peroxidation of membrane lipids, sulfhydryl enzyme inactivation, protein cross-linking and DNA breakdown. This damage may be involved in the etiology of diverse human diseases. ${ }^{16,18-22}$ Consequently, organ damage may further increase ROS production.

One of the proposed mechanisms of chronic ethanol inducedtoxicity is the membrane damage due to the direct effect of lipid peroxidation products, ${ }^{13}$ i.e., TBARS, which was found to be increased in the ethanol exposed rats in the present study (Table 2). Chronic alcohol ingestion enhanced superoxide generation in the lung tissue. ${ }^{23}$ Protein nitration has been suggested to be a final product of highly reactive nitrogen oxide intermediates (e.g., peroxynitrite) formed in reactions between $\mathrm{NO}$ and oxygen-derived species such as superoxide. Nitrite is a stable metabolite of $\mathrm{NO}$ in vivo. Increased nitrite level was observed in lung homogenate of ethanol exposed rats in the present study (Table 2) through the 


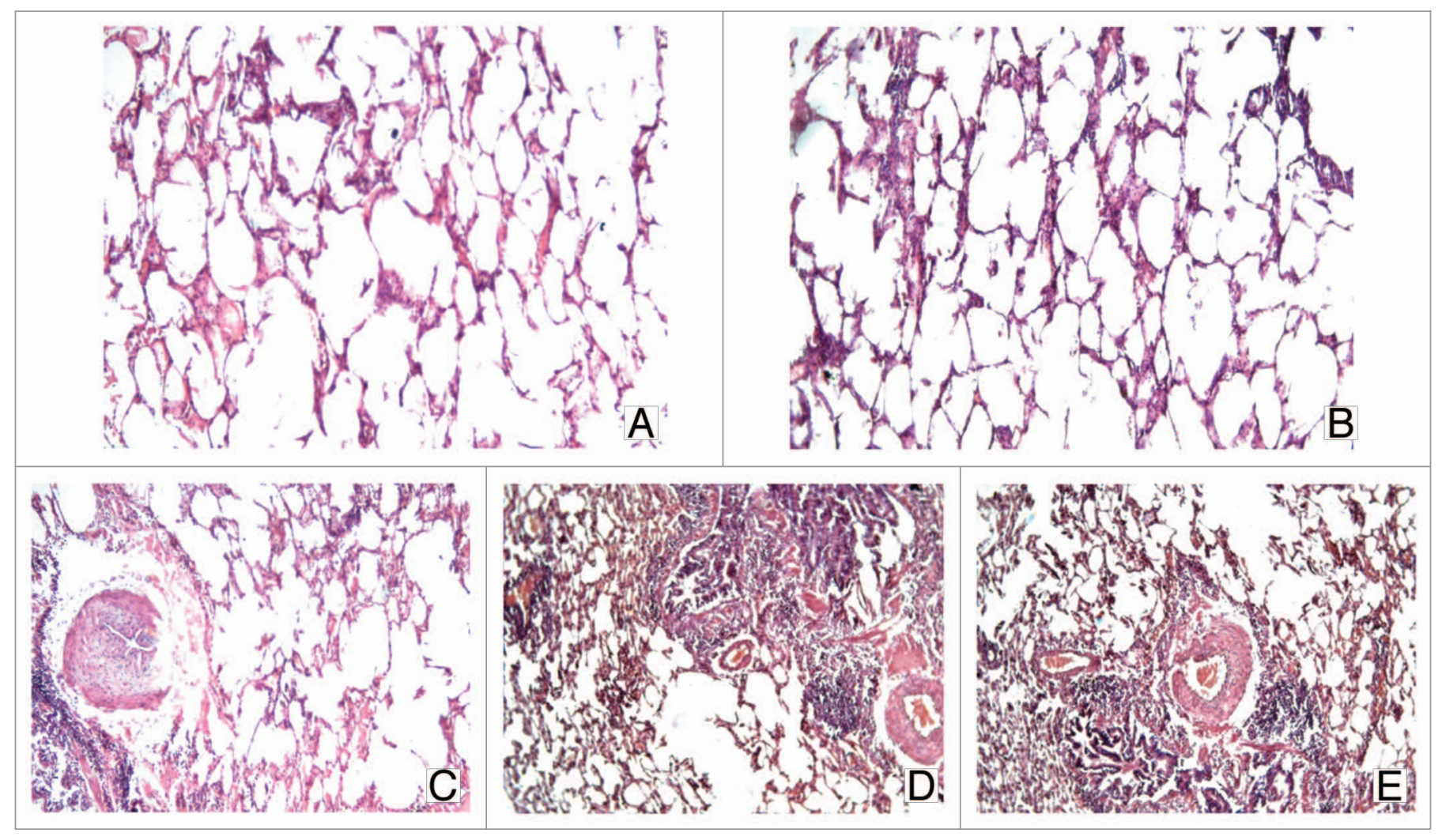

Figure 2. Lung tissues fixed in formalin, processed for hematoxylin and eosin stain to assess morphological changes under microscope. (A) Normal texture of lung in control animals; (B) 4 weeks ethanol treated lung with mild inflammation; (C) 12 weeks ethanol treated rat-Lung alveoli with marked interstitial infammation with inflammatory exudates in some of the alveoli; (D) 24 weeks ethanol treated rats-Lung alveoli filled with inflammatory exudates; (E) 36 weeks ethanol treated rat-severe inflammation.

Table 4. Leokocyte infiltration score of the control and ethanol exposed groups

\begin{tabular}{cccccc} 
Group & \multicolumn{5}{c}{ Leukocyte infiltration score } \\
& $\mathbf{0}$ & $\mathbf{1}$ & $\mathbf{2}$ & $\mathbf{3}$ & total \\
$\begin{array}{c}\text { Control } \\
\text { (0 week) }\end{array}$ & 5 & 1 & - & - & 6 \\
\hline 4 week & - & 2 & 3 & 1 & 6 \\
\hline 12 week & - & 1 & 3 & 2 & 6 \\
\hline 24 week & - & 2 & 3 & 2 & 7 \\
\hline 36 week & - & 1 & 4 & 3 & 8 \\
\hline
\end{tabular}

Leukocyte infiltration was evaluated to determine the severity of oxidative damage in the lung. Each section was divided into subsections, and leukocyte infiltration was assessed using the scale for comparison at a magnification of X400: $0=$ no extravascular leukocytes; $1 \leq 10$ leukocytes; $2=10$ - 45 leukocytes; and $3 \geq 45$ leukocytes.

activation of a constitutive nitric oxide synthase (NOS), most likely the endothelial NOS isoform (eNOS or NOS-3). ${ }^{24}$

The tissue GSH concentration reflects its potential for detoxification and is critical in preserving the proper cellular redox balance for its role as a cellular protectant. ${ }^{25}$ During the detoxification of lipid and other peroxides produced by free radical attack, glutathione peroxidase converts glutathione from a reduced state (GSH) to an oxidized one (GSSG). ${ }^{26}$ The NADPH-dependent enzyme glutathione reductase converts GSSG back to GSH, and so almost all intracellular glutathione is reduced. During an oxidative stress, there will be a flux of glutathione to the oxidized form, and the ratio of oxidized to reduced glutathione may then be indication of this stress. ${ }^{27}$ Decreased GSH level, increased GSSG level and redox ratio with duration of ethanol exposure indicated time dependent elevation of oxidative stress in the lung in this study (Table 2).

Chronic ethanol ingestion resulted in significant decrease in GPx activity in the lung may be due to either free radical dependent inactivation of enzyme or depletion of its substrates i.e., GSH and NADPH. ${ }^{13,14}$ Glutathione s-transferase (GST) plays an essential role by eliminating toxic compounds by conjugating them with glutathione. Increased GST activity, and decreased GPx and GR activities (Table 3), followed by thiol depletion (Table 2) are important factors in sustaining a pathogenic role for oxidative stress. ${ }^{13,14,28}$

The presence of superoxide dismutase (SOD) in various compartments of human body enables SOD to dismutate superoxide radical immediately. ${ }^{13}$ The cytochrome $\mathrm{P} 450$ 2E1 was demonstrated to generate higher amounts of $\mathrm{H}_{2} \mathrm{O}_{2},{ }^{29}$ and is linked to increased generation of hydroxyl radicals. ${ }^{30}$ Decreased SOD and catalase activities with duration of ethanol exposure in the lung in this study (Table 3) may be due to loss of NADPH, or generation of superoxide, or increased lipid peroxidation or combination of all. ${ }^{13}$ 
$\mathrm{Na}^{+}-\mathrm{K}^{+}$ATPase participates in lung fluid clearance by creating the active transport of sodium. ${ }^{31}$ Oxidative stress plays a role in mediating the ethanol-induced downregulation of lung $\mathrm{Na}^{+}-\mathrm{K}^{+}$ ATPase in this study. GSH depletion seems to be a major determinant of this effect. ${ }^{32}$ Increased lipid peroxidation combined with decreased tissue $\mathrm{Na}^{+}-\mathrm{K}^{+}$ATPase activity in the lung in this study (Table 3) may be associated with impairment of membrane phospholipids. ${ }^{33}$ The decreased enzyme activity gives rise to the disintegration of the cells and consequently to the thickening of the air-blood barrier, alveolar degeneration and leukocyte infiltration, ${ }^{31}$ as observed histopathologically in the lungs of the ethanol-exposed rats (Fig. 2 and Table 4). Ethanol-induced reactive species causes phenotypic alterations in the lung and alters the lung's response to inflammatory stimuli. ${ }^{36}$ These inflammatory mediators lead to leukocyte activation, expression of endothelial adhesion molecules and vascular endothelial damage. ${ }^{34}$

The alveolar extracellular matrix (ECM) is considered to be a static structural component of the lung tissue. It serves as a modulator of cell growth and development, inflammation, angiogenesis, cell migration, tissue differentiation and repair. There is growing evidence that aberrant remodeling of the ECM contributes both to the early inflammatory phase as well as to the later fibroproliferative phase of the syndrome. ${ }^{35,36}$ Evidence suggests that degradation of the ECM by (MMPs) may contribute to the development of lung injury, ${ }^{37}$ as observed in this study (Fig. 1).

Though biochemical alterations and oxidative stress related parameters respond early in alcoholism than the histopathological changes; ${ }^{38}$ leukocyte infiltration and matrix metalloproteinases activation were observed in ethanol-treated lungs and its severity increased with duration of ethanol exposure in the present study. In conclusion, our results suggest that long-term ethanol administration aggravates systemic and local oxidative stress, which is one of the leading causes of lung injury.

\section{Methods}

Materials. Ethanol was purchased from Bengal Chemicals, Kolkata. Chemicals from Sisco Research Laboratory (SRL), India, Sigma Chemical Co., St. Louis, MO; and E. Merck were used. Ethanol was diluted with distilled water to get desired concentration and fed orally, when necessary.

Animals and treatment. The male albino rats (16-18 weeks old) of Wistar strain weighing 200-220 g were housed in plastic cages inside a well-ventilated room, with the room temperature maintained at $25 \pm 2^{\circ} \mathrm{C}$, with a $12 \mathrm{~h} \mathrm{light/dark} \mathrm{cycle.} \mathrm{Animals}$ had free access of standard diet ${ }^{14}$ containing (\%) bengal gram, 31; gingelly oil cake, 30; wheat, 28; polished rice, 10; salt mixture, 0.5; vitamin-mineral mixture, 0.3 ; and yeast with fish or liver oil, 0.2. Food and water were given ad libitum. Animals were weighed daily and their general condition and behavior were recorded, including their daily intake of food.

The rats were divided into the following five groups of 6 animals each. Group 1: control-were fed normal diet and water; Group 2: ethanol (1.6 g ethanol $/ \mathrm{kg}$ body wt/day) treated for 4 wks; Group3: ethanol (1.6 g ethanol/kg body wt/day) treated for 12 wks; Group 4: ethanol (1.6 g ethanol/kg body wt/day) treated for 24 wks; Group 5: ethanol (1.6 g ethanol/kg body wt/day) treated for 36 wks.

At the end of the experimental period, blood samples were collected from retro-orbital plexus of rats. The animals were then sacrificed after overnight fast, by intraperitoneal injection of sodium pentobarbital (50 mg/ $\mathrm{kg}$ body wt). The lung was dissected out, cleaned with ice-cold saline, blotted dry and immediately transferred either to the ice chamber for biochemical studies or fixed in $10 \%$ buffered formal saline for histopathological examinations. Various oxidative stress related non-enzymes such as TBARS, nitrite, protein carbonyl, GSH, GSSG; and enzymes activities such as GR, GPx, GST, catalase, SOD and $\mathrm{Na}^{+} \mathrm{K}^{+}$ATPase were estimated. The Animal Ethics Committee of the Institution approved the procedures in accordance with the CPCSEA guideline.

Biochemical methods. Blood collected from retro-orbital plexus was used for blood ethanol concentration estimation using an ethanol assay kit (Sigma).

Lung samples were homogenized in $0.25 \mathrm{M}$ sucrose solution, and were used to estimate tissue protein. ${ }^{39}$

Determination of thiobarbituric acid reactive substances (TBARS). Lung samples were homogenized in ice-cold $0.25 \mathrm{M}$ tris buffer ( $\mathrm{pH} 7.4$ ). $0.3 \mathrm{ml}$ of this homogenate was mixed thoroughly with $2 \mathrm{ml}$ of TCA-TBA-HCl [trichloroacetic acid (TCA) $15 \% \mathrm{w} / \mathrm{v}$, thiobarbituric acid (TBA) $0.375 \% \mathrm{w} / \mathrm{v}$ and hydrochloric acid $(\mathrm{HCl}) 0.25 \mathrm{~N}$ ]. The solutions were heated for $15 \mathrm{~min}$ in a boiling water bath, cooled; the flocculent precipitates were removed, and the absorbance was recorded at $535 \mathrm{~nm}$. The extent of lipid peroxidation was calculated using molar extinction coefficient $1.56 \times 10^{5} \mathrm{M}^{-1} \mathrm{~cm}^{-1} .^{40}$

Nitrite estimation. Sulfanilamide $(1 \%, 50 \mu \mathrm{l})$ in $2.5 \%$ orthophosphoric acid (Griess reagent 1), followed by N-(1-naphthyl) ethylenediamine $(0.1 \%, 50 \mu \mathrm{l})$ in distilled water (Griess reagent 2$)$ were added to the tissue homogenate, incubated in dark at room temperature for $10 \mathrm{~min}$. The absorbance was measured at $540 \mathrm{~nm}$. The concentration of nitrite was measured by using $\mathrm{NaNO}_{2}$ as a standard. ${ }^{41}$

Protein-carbonyl content. Proteins were precipitated with $20 \%$ trichloroacetic acid and centrifuged. The precipitates were resuspended in 2,4-dinitrophenylhydrazine $(10 \mathrm{mM})$ and vortexed at $10 \mathrm{~min}$ intervals for $1 \mathrm{~h}$ at room temperature. The pellets were washed thrice with ethanol/ethyl acetate, resuspended in $0.6 \mathrm{ml}$ of $6 \mathrm{M}$ guanidine hydrochloride, incubated at $37^{\circ} \mathrm{C}$ for $15 \mathrm{~min}$ and centrifuged at 5,000 $\mathrm{g}$ for $3 \mathrm{~min}$. The absorbance of supernatant was measured at $366 \mathrm{~nm}$ for carbonyl content, and calculations were performed with $\varepsilon$ value of $22,000 \mathrm{M}^{-1} \mathrm{~cm}^{-1}{ }^{4}{ }^{42}$

Glutathione content. The lung (-100 mg) samples were homogenized in ice-cold $0.1 \mathrm{M}$ phosphate buffer ( $\mathrm{pH} 7.4$ ). For reduced glutathione (GSH) content, the homogenates were immediately mixed with sulfosalicylic acid, shaked well and centrifuged. Each supernatant fraction was mixed separately with 5,5'-dithiobis(2nitrobenzoic acid) (in $0.01 \mathrm{M}$ phosphate buffer, $\mathrm{pH}$ 8) and absorbance was recorded at $412 \mathrm{~nm} .{ }^{43}$ For oxidized glutathione, $200 \mu \mathrm{l}$ supernatant was added to $3.78 \mathrm{ml}$ of water to which $40 \mu \mathrm{l}$ of 2-vinylpyridine was mixed to mask the GSH and left at room temperature for $3 \mathrm{~h}$ before estimation as described above. ${ }^{44}$ 
Glutathione reductase (GR, EC 1.6.4.2) activity. The tissues were homogenized in phosphate buffer $(0.12 \mathrm{M}, \mathrm{pH} 7.2)$, and were mixed to $15 \mathrm{mM}$ EDTA in phosphate buffer and $9.6 \mathrm{mM}$ NADPH. The reaction was initiated by adding oxidized glutathione (GSSG, $65.3 \mathrm{mM}$ ). Change in absorbance was monitored at $340 \mathrm{~nm}$; and the specific activity was determined using extinction coefficient for NADPH of $6.22 \mathrm{~cm}^{-1} / \mu \mathrm{M} .45$

Glutathione peroxidase (GPx, EC 1.11.1.9) activity. Glutathione peroxidase activity was measured based on the principle that oxidized glutathione produced by GPx is reduced at a constant rate by glutathione reductase with NADPH as a cofactor. NADPH allows maintaining predictable levels of reduced glutathione. The oxidative rate of NADPH was monitored at $340 \mathrm{~nm}^{4}{ }^{46}$

Glutathione-s-transferase (GST; EC 2.5.1.18) activity. The tissues were homogenized using phosphate buffer $(0.05 \mathrm{M}, \mathrm{pH}$ 6.5). 1-chloro-2,4-dinitrobenzene (CDNB) in phosphate buffer was mixed with reduced glutathione, and then tissue extract was added. The change in absorbance was monitored at 340 $\mathrm{nm}$, and calculated from extinction coefficient $9.6 \mathrm{mM}^{-1} \mathrm{~cm}^{-1} .{ }^{47}$

Catalase (EC 1.11.1.6) activity. The tissues were homogenized in $0.05 \mathrm{M}$ phosphate buffered saline ( $\mathrm{pH}$ 7.0). The rate of decomposition of $\mathrm{H}_{2} \mathrm{O}_{2}(2 \mu \mathrm{l}, 30 \%)$ in $0.05 \mathrm{M}$ phosphate buffer $(1 \mathrm{ml}, \mathrm{pH} 7.0)$ at $240 \mathrm{~nm}$ after addition of homogenized tissue was noted. The specific activity was calculated assuming molar extinction coefficient $22,000 \mathrm{M}^{-1} \mathrm{~cm}^{-1}$ at $240 \mathrm{~nm} .{ }^{14}$

Superoxide dismutase (SOD, EC 1.15.1.1) activity. Superoxide dismutase activity was measured by the inhibition of auto-oxidation of $0.2 \mathrm{mM}$ pyrogallol (air equilibriated) in 50 $\mathrm{mM}$ at Tris- $\mathrm{HCl}$ buffer ( $\mathrm{pH}$ 8.2) containing $1 \mathrm{mM}$ diethylenetriamine pentaacetic acid. The rate of autooxidation was monitored at $420 \mathrm{~nm}$. The inhibition of pyrogallol autooxidation was initiated by addition of tissue homogenate. ${ }^{48}$

\section{References}

1. Das SK. Effects of alcohol in the lung. Curr Resp Med Rev 2009; 5:28-40.

2. Osler WM. In: The Principles and Practices of Medicine. Appleton \& Lange, New York 1905.

3. Joshi PC, Guidot DM. The alcoholic lung: epidemiology, pathophysiology and potential therapies. Am J Physiol Lung Cell Mol Physiol 2007; 292:813-23.

4. Moss M, Bucher B, Moore FA, Moore EE, Parsons PE. The role of chronic alcohol abuse in the development of acute respiratory distress syndrome in adults. JAMA 1996; 275:50-4

5. Ashbaugh DG, Bigelow DB, Petty TL, Levine BE. Acute respiratory distress in adults. Lancet 1967; 2:319-23.

6. Eastwood MA, Passmore R. In: Human nutrition and dietetics. ELBS/Charchill Livingstone 1986; 70-223.

7. Antia EP, Abraham P. In: Clinical Dietetics and Nutrition. Oxford University Press 1997; 240-8.

8. Cunningham CC, Bailey SM. Ethanol consumption and liver mitochondria function. Biological Signals and Receptors 2001; 10:271-82.

9. Lieber CS. Biochemical factors in alcoholic liver disease. Semin Liver Dis 1993; 13:136-53.

10. Das SK, Vasudevan DM. Alcohol induced oxidative stress. Life Sciences 2007; 81:177-87.

11. Manatou JE, Buss NJ, Carlson GP. Oxidative and nonoxidative metabolism of ethanol by the rabbit lung. Toxicol Lett 1992; 62:93-9.
$\mathrm{Na}^{+}-\mathrm{K}^{+}$ATPase activity. Specific activity of $\mathrm{Na}^{+}-\mathrm{K}^{+}$ATPase estimation is based on the principle that the inorganic phosphate is released from protein in presence of $3 \mathrm{mM}$ disodium adenosine 5 -triphosphate in incubation medium. ${ }^{49}$

Multiwell zymogram (Total MMP activity). $100 \mu \mathrm{l}$ tissue samples were placed in 24-well containing plate and incubated at $37^{\circ} \mathrm{C}$ for $30 \mathrm{mins}$ for enzyme activation. Zymo gel $(15 \mathrm{mg}$ gelatin dissolved in $3.75 \mathrm{ml}$ of Tris buffer $\mathrm{pH}(8.8), 3.75 \mathrm{ml}$ acrylamide-bisacryamide (30:0.3), $7.125 \mathrm{ml}$ double distilled water, $150 \mu \mathrm{l}$ 10\% ammonium persulphate (freshly prepared) and 15 $\mu \mathrm{l}$ TEMED) was added and allowed to settle for $1 \mathrm{~h}$. The gels were then placed in 6-well containing plates with zymo buffer (calcium chloride buffer, $\mathrm{pH} 7.5: 3.03 \mathrm{~g}$ Tris- $\mathrm{HCl}$ and $0.36 \mathrm{mg}$ $\mathrm{CaCl}_{2}$ dissolved in $500 \mathrm{ml}$ double distilled water) and incubated overnight. After removing the zymo buffer, the gels were stained with Coomasie brilliant blue for 3 to $4 \mathrm{~h}$. The gels were finally destained with methanol-acetic acid-water. ${ }^{50}$

Histopathological examination. Lung tissues fixed in 10\% formalin, routinely processed and embedded in paraffin. Sections were cut ( $4 \mu \mathrm{m}$ thick) and stained with hematoxylin and eosin to assess morphological changes under microscope. Leukocyte infiltration was evaluated to determine the severity of oxidative damage that resulted from ethanol intoxication. Each section was divided into 10 subsections, and leukocyte infiltration was assessed using the following scale for comparison at a magnification of x 400: $0=$ no extravascular leukocytes; $1 \leq 10$ leukocytes; $2=10-45$ leukocytes; and $3 \geq 45$ leukocytes.

Statistical analysis. Results were expressed as mean $\pm S D$ (standard deviation). All statistical analysis were performed by one-way analysis of variance (ANOVA) with multiple comparison tests and student's t-test using the Statistical Package for Social Sciences, version 11 (SPSS, Chicago, IL). The values of significance were evaluated with $\mathrm{p}$ values. The differences were considered significant at $\mathrm{p}<0.05$.
12. George SC, Hlastala MP, Souders JE, Babb AL. Gas exchange in the airways. J Aerosol Med 1996; 9:25-33.

13. Das SK, Vasudevan DM. Effect of ethanol on liver antioxidant defense systems: a dose dependent study. Indian J Clin Biochem 2005; 20:80-4.

14. Das SK, Vasudevan DM. Modulation of lecithin activity by vitamin-B complex to treat on ethanol induced oxidative stress in liver. Indian J Exp Biol 2006; 44:791-6.

15. Froehlich JC, Stewart RB, Li TK, Mosemiller AK, McCullough DE, Ho MC, et al. Induction of steadystate blood alcohol levels: application to the study of within-session alcohol tolerance in rats. Alcohol Clin Exp Res 2001; 25:370-6.

16. Moss M, Guidot DM, Wong-Lambertina M, Ten Hoor T, Perez RL, Brown LAS. The effects of chronic alcohol abuse on pulmonary GSH homeostasis. Am J Respir Crit Care Med 2000; 161:414-9.

17. Holguin F, Moss IM, Brown LS, Guidot DM. Chronic ethanol ingestion impairs alveolar type II cell glutathione homeostasis and function and predisposes to endotoxin-mediated acute edematous lung injury in rats. J Clin Invest 1998; 101:61-8.

18. Lang JD, McArdle PJ, O'Reilly PJ, Matalon S Oxidant-antioxidant balance in acute lung injury. Chest 2002; 122:314-20.

19. Carden DL, Granger DN. Pathophysiology of ischemia-reperfusion injury. J Pathol 2000; 190:255-66.
20. Fischer W. Lipoteichoic acid and lipids in the membrane of Staphylococcus aureus, Med Microbiol Immunol (Berl) 1994; 183:61-76.

21. Seekamp A, Ward PA. Ischemia-reperfusion injury. Agents Actions Suppl 1993; 41:137-52.

22. van der Vliet A, Cross CE. Oxidants, nitrosants and the lung. Am J Med 2000; 109:398-421.

23. Polikandriotis JA, Rupnow HL, Elms SC, Clempus RE, Campbell DJ, Sutliff RL, et al. Chronic ethanol ingestion increases superoxide production and NADPH oxidase expression in the lung. Am J Respiratory Cell Mol Biol 2006; 34:314-9.

24. Polikandriotis JA, Rupnow HL, Brown LA, Hart CM. Chronic ethanol ingestion increases nitric oxide production in the lung. Alcohol 2007; 41:309-16.

25. Mari M, Wu D, Nieto N, Cederbaum AI. CYP2E1 dependent toxicity and upregulation of antioxidant genes. J Biomed Sci 2001; 8:52-5.

26. Owens CW, Belcher RV. A colorimetric micro-method for the determination of glutathione. Biochem J 1965; 94:705-11.

27. Griffith OW. In: Glutathione and glutathione disulphide. Berlin VCH 1985; 521.

28. Aniya Y, Daido A. Activation of microsomal glutathione S-transferase in tert-butyl hydroperoxide-induced oxidative stress of isolated rat liver. Jpn J Pharmaco 1994; 66:123-30 
29. Nordsblom GD, Coon MJ. Hydrogen peroxide formation and stoichiometry of hydroxylation reactions catalyzed by highly purified liver microsomal cytochrome p450. Arch Biochem Biophys 1977; 180:343-7.

30. Klein SM, Cohen G, Lieber CS, Cederbaum AI Increased microsomal oxidation of hydroxyl radical scavenging agents and ethanol after chronic consumption of ethanol. Arch Biochem Biophys 1983; 223:425-32.

31. Aytacoglu BN, Calikoglu M, Tamer L, Coskun B, Sucu $\mathrm{N}$, Köse N, et al. Alcohol-induced lung damage and increased oxidative stress. Respiration 2006; 73:100-4.

32. Rodrigo R, Trujillo S, Bosco C, Orellana M, Thielemann L, Araya J. Changes in $\left(\mathrm{Na}^{+} \mathrm{K}\right)$ adenosine triphosphatase activity and ultrastructure of lung and kidney associated with oxidative stress induced by acute ethanol intoxication. Chest 2002; 121:589-96.

33. Kolanjiappan K, Manoharan S, Kayalvizhi M. Measurement of erythrocyte lipids, lipid peroxidation, antioxidants and osmotic fragility in cervical cancer patients. Clin Chim Acta 2002; 326:143-9.

34. Calikoglu M, Tamer L, Sucu N, Coskun B, Ercan B, Gul A, et al. The effects of caffeic acid phenethyl ester on tissue damage in lung after hindlimb ischemiareperfusion. Pharmacol Res 2003; 48:397-403.

35. Matsubara O, Tamura A, Ohdama S, Mark EJ. Alveolar basement membrane breaks down in diffuse alveolar damage: an immunohistochemical study. Pathol Int 1995; 45:473-82.
36. Hayashi T, Stetler-Stevenson WG, Fleming MV, Fishback N, Koss MN, Liotta LA, et al Immunohistochemical study of metalloproteinases and their tissue inhibitors in the lungs of patients with diffuse alveolar damage and idiopathic pulmonary fibrosis. Am J Pathol 1996; 149:1241-56.

37. Delclaux C, D'Ortho MP, Delacourt C, Lebargy F Brun-Buisson C, Brochard L, et al. Gelatinases in epithelial lining fluid of patients with adult respiratory distress syndrome. Am J Physiol 1997; 272:442-51.

38. Das SK, Hiran KR, Mukherjee S, Vasudevan DM Oxidative stress is the primary event in brain: effects of ethanol consumption. Indian J Clin Biochem 2007; 22:99-104.

39. Lowry $\mathrm{OH}$, Rosenbourgh NJ, Farr AL, Randall RJ. Protein measurement with folin phenol reagent. J Biol Chem 1951; 193:265-75.

40. Sinnhuber RO, Yu TC, Yu TC. Characterization of the red pigment formed in the thiobarbituric acid determination of oxidative rancidity. Food Res 1958; 23:626-30.

41. Kleinbongard P, Rasaf T, Dejam A, Kerber S, Kelm M. Griess method for nitrite measurement of aqueous and protein containing sample. Meth Enzymol 2002; 359:158-68.

42. Bhatwadekar AD, Ghole VS. Rapid method for the preparation of an AGE-BSA standard calibrator using thermal glycation. J Clin Lab Anal 2005; 19:11-5.
43. Ellman GL. The sulphydryl groups. Arch Biochem Biophys 1959; 32:70-7.

44. Teare JP, Punchard NA, Powell JJ, Lumb PJ, Mitchell WD, Thompson RP. Automated spectrophotometric method for determining oxidized and reduced glutathione in liver. Clin Chem 1993; 39:686-9.

45. Goldberg MD, Spooner JR. Glutathione reductase. In Bergmayer HU, Bergmayer J, Grabi M, Ed. Methods Enzyme Analysis. $3^{\text {rd }}$ edn, Academic Press Inc., Florida 1983; 3:58-65.

46. Paglia DE, Valentine WN. Studies on the quantitative and qualitative characterisation of erythrocyte glutathione peroxides. J Lab Clin Med 1967; 70:158-9.

47. Habig WH, Pabst MJ, Jakoby WB. Glutathione S-transferase, the first enzymatic step in mercapturic acid formation. J Biol Chem 1974; 249:7130-9.

48. Marklund S, Marklund G. Involvement of superoxide radical in the auto oxidation pyrogallol and a convenient assay for superoxide dismutase. Eur J Biochem 1974; 47:469-74.

49. Reading HW, Isbir T. Action of lithium on ATPases in the rat iris and visual cortex. Biochem Pharmacol 1979; 28:3471-4

50. Ambili M, Sudhakaran PR. Assay of matrix metalloproteinases in substrate impregnated gels in multiwells. Indian J Biochem Biophys 1998; 35:317-20 


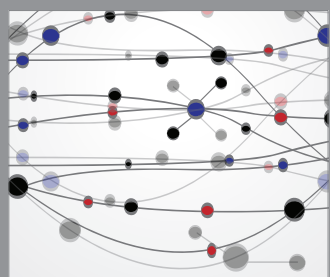

The Scientific World Journal
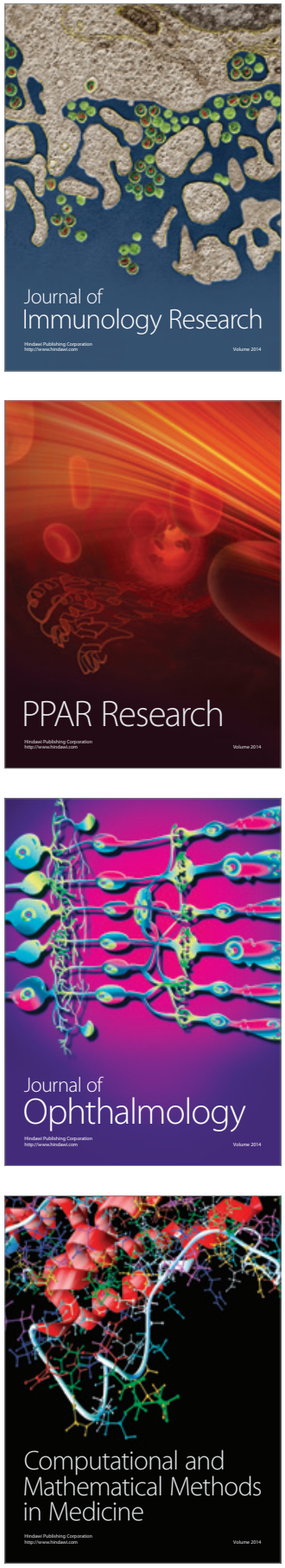

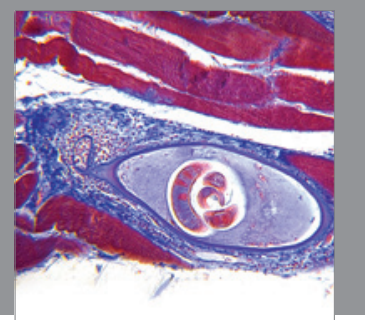

Gastroenterology

Research and Practice
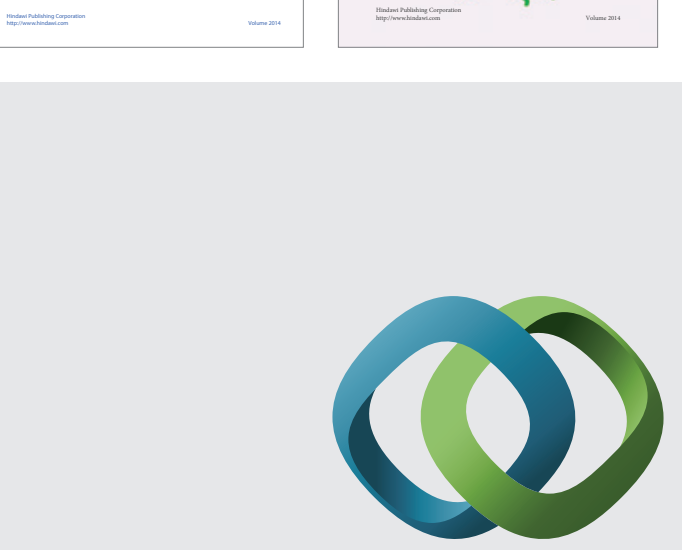

\section{Hindawi}

Submit your manuscripts at

http://www.hindawi.com
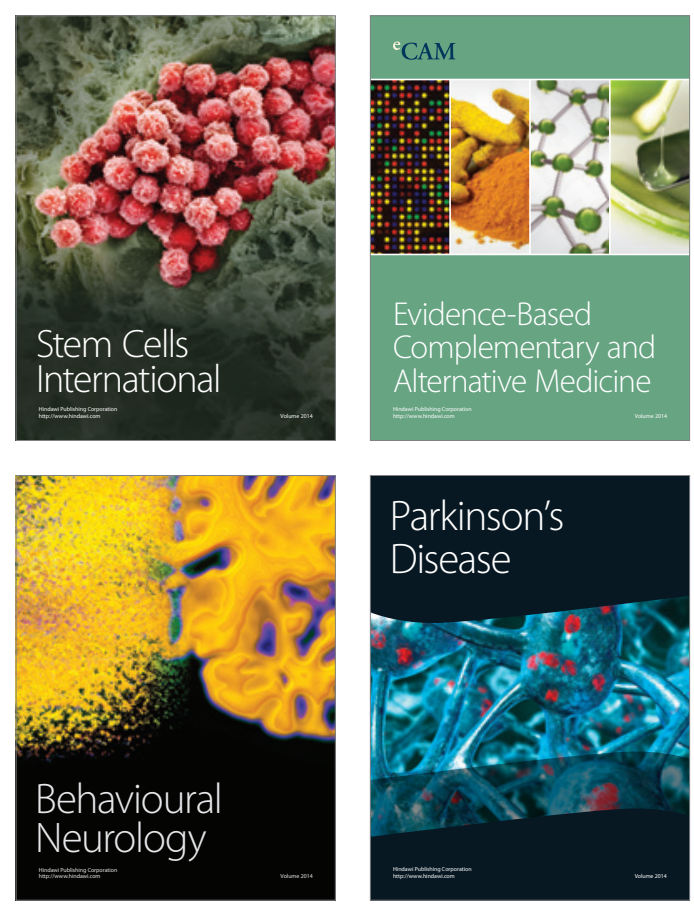

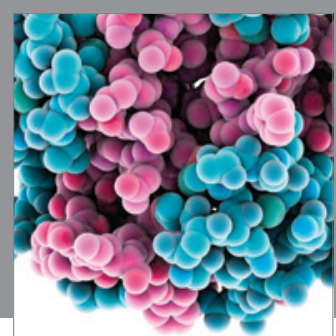

Journal of
Diabetes Research

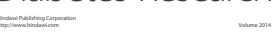

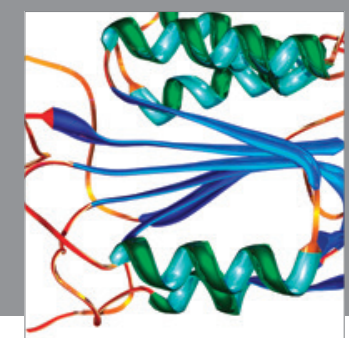

Disease Markers
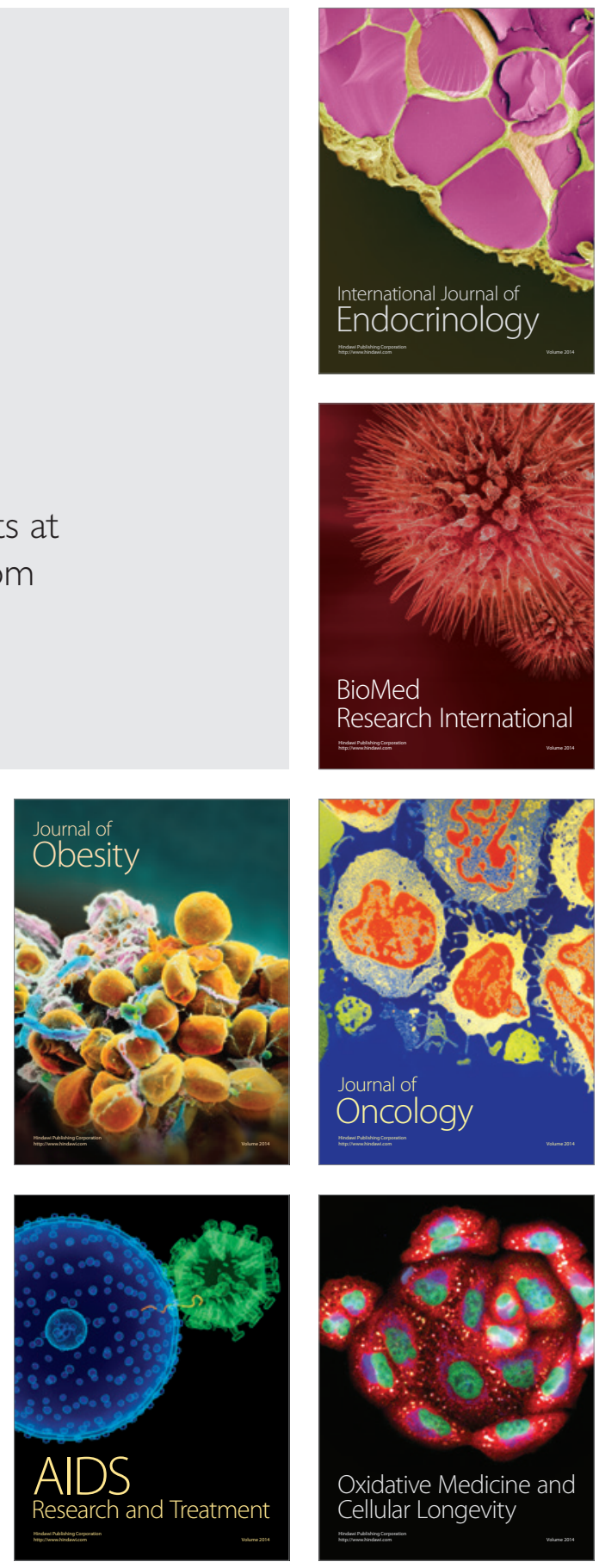